\title{
Chapter 14. Finishing the Land: Identity and Land Use in Pre- and Post-Colonial North Ambrym
}

\author{
Mary Patterson
}

\section{Introduction}

The first wave of scholars interested in the archipelago of Vanuatu, known as the New Hebrides before 1980, made frequent reference in their work to continuities and commonalities linking the region to its north-west, but it is in the work of linguists and archaeologists rather than in anthropology that Vanuatu's position in the Austronesian world has been recently established. In most of the work of the second wave of scholars working in the colonial period in Vanuatu, from the 1950s to the late 1970s, anthropologists were much more likely to refer to theoretical issues arising from work in Melanesia, for which PNG is frequently the metonym, or even to Australia, rather than to Austronesia.

Some of the work of that period focusing on land and place in Vanuatu, mostly published in the 1980s, brought out two master tropes of 'ethnoscapism': rootedness in place and mobility (Bonnemaison 1985). For Bonnemaison, Melanesian ethno-geography is characterised by reticulated space or networks, in which places are linked by alliances where there is no dominant centre, only foundation or primordial places (Bonnemaison 1996: 36-8). These notions seem eminently compatible with some of the core ideas identified by Fox as prominent and enduring features of Austronesian communities, such as concern with a multiplicity of origins, use of terms such as 'path' and 'road' as metaphors for important links between founder-focused groups and a concern that the blood or flow of life carried by female descendants of founders should be returned to the group of origin by means of some form of recursive marriage between descendants (Fox 1993, 1997; Fox and Sather 1996). All of these features are important in north Ambrym, an island in northern Vanuatu that is the focus of this chapter.

In foregrounding the importance of place and place-making in the Austronesian world, the Comparative Austronesian Studies Project offers the opportunity to consider the political dynamism involved in the local development and reinterpretation of old concepts in a region with a commonality of conflicts relating to land and identity. I begin with a brief overview of the vocabulary of 'place' in the national arena in Vanuatu since independence, then in the works of various authors writing about the north and north-central regions where 
various common usages are found that will be familiar to Austronesian scholars. I follow this with more specific detail on the somewhat different vocabulary in North Ambrym before proceeding to a discussion of the contemporary context in which land metaphors and the mythopoesis of earth and place have been played out in that island.

\section{Land and National Consciousness in Vanuatu}

Throughout Vanuatu, the words 'vanua' and 'tan' while having varied local salience, have entered the vocabulary of the nation state as part of indigenous political discourse about land and identity. In order to understand this local politics, we need to appreciate the importance of 'place-making' as an aspect of claims to precedence in an environment in which primordialism and movement into and out of place are valued and contested (Rodman 1992, 1994; Patterson 2002). Place-making at the national level, however, involved land in a rather different context that had emerged long before the colony of the New Hebrides became the Republic of Vanuatu in 1980. This is not surprising, of course, in an archipelago in which vast tracts of the most productive land had been alienated by Europeans. In consequence, the indigenous political groups that emerged in the 1970s saw land issues as the basis of their case for decolonisation and their rhetorical appeal to the varied populations of the islands (Lini 1980; Sope 1974; Van Trease 1987).

Two islands, Tanna and Vanua Lava in the Banks Graip, already incorporated the words we are investigating in their names, from the period of European exploration. When it came to a new name for the independent republic, the members of the first major political party were in no doubt about what should be the focus of such a name as they soon realised it should also be for the party they had formed. According to Walter Lini, who became the first Prime Minister of Vanuatu, the name of the party was changed from the New Hebrides National Party to the Vanua'aku Pati because 'we decided that the name of our country should become Vanua'aku' (Lini 1980: 26). I have so far searched in vain for anything that explains how the 'aku' in the Republic's name transmogrified to 'atu', but I suspect that the Vanua'aku Pati members were convinced by their opponents and friends that the name of the country should not be that of a political party. The details of this decision and the choice of word has not, as far as I know, been published. 'Atu' is translated from an unspecified language as variously 'has arisen' or 'stands up'. Walter Lini, and most of the other members of the proto-government (and later the elected government), came from islands in which 'vanua' rather than 'tan' featured as a polysemic word for land, domain, village site, and even men's house.

Two other political parties, both opposed to the Vanua'aku Party, incorporated ' $t a n^{\prime}$ ' in their name; one calling itself Natui Tano or 'the children of the land' was short-lived. ${ }^{1}$ The other, Tan Union, a Francophone party, emerged in 1977 in 
opposition to the anti-Independence Francophones and the Vanua'aku Pati (Boulekone 1995: 198). Unlike Natui Tano, which, according to Van Trease, was merely

an extension of the New Hebrides National Party shortly to be renamed as mentioned above, and ... relatively short-lived, fielding candidates at only one election, Tan Union remained a force in local politics until recently. (Van Trease 1987: 216)

At the local level, the vocabulary and discourse of land and place are also refracted through the struggle for independence and the coming to prominence of the ideology of man-ples, a Bislama (Vanuatu pidgin) term that is also deeply contextual with its meanings of 'indigenous person, primary landholder, recognised descendant of a founder of place'. These contexts frequently make local words extremely difficult to translate into a language such as English where the connection between people and places is overtly distinguished.

Preliminary inquiries into land and place categories in northern Vanuatu show a distribution that tends to feature one or the other of the vanua and tan terms. Although both words might be present, if 'vanua' is prominent in local discourse then ' $t^{\prime} n^{\prime}$ is not, and vice versa. In Ambrym and South Pentecost there appears to be no reflex of 'vanua'. In Vao, one of the small islands off north-east Malakula, Layard gives venu and vanu as 'village' or 'place' - as in translation of the village name Togh-Vanu (Layard 1942: 75). In mainland Malakula, 'vene' appears as part of clan names in a description of the Nogho rites but no translation is offered (Deacon 1934). In Malo, tan appears as part of clan names (Hume 1985). In East Ambae, 'vanue' is important but 'tano' less so. Writing of this region, Margaret Rodman says, 'Vanue is not land (tano), it is lived space in which place and people are part of each other' (1987: 35). However, we do find both words in some places, as noted above, and other words with similar meanings but apparently different origins, in others. In the Banks Islands, according to Codrington the village site is referred to as 'vanua' while house sites are called 'tano ima' (Codrington 1957 [1891]: 65). Vienne, who worked in the Banks from the late 1960s to the early '70s, gives a more lyrical and nuanced account of the relationship between vanua and tan. He says:

On the ocean float the islands: the vanua. The matter that constitutes the vanua is the tano, the earth, but also the place, the space, the land, the apparent and particular toponymic form of the 'vanua'. The relations lama/tas (ocean/sea) and vanua/tano are in fact more complex than a simple opposition between space and matter. The two oppositions, taking into account the ensemble of their meanings, divide in a parallel manner, contrasting term by term from the general to the specific. (Vienne 1984: 69; my translation.) 
He elucidates further:

In this sense the vanua is also 'home', the free and appropriated space, dominated and known by those who belong to you and to whom you belong. The vanua is inscribed in the ' $m o t$ ' which is contained by and distinguished as uncultivated space, the wild, home of spirits and enemies, opposed to cultivated space, the domestic, home of men. The 'mot' is the Vanua gona, the closed space - the territory of spirits. (Ibid.)

In West Ambae, Michael Allen noted the segmentary and polysemic character of the vanua term. While noting that the earth as substance is tano, vanua, according to context, can represent the whole island of Ambae, 'a district, a village, a village section or simply an individual's land' (Allen 1969: 132). But the definition of the maximal segment identified by Allen as the village or ngwatu $i$ vanua (literally, the 'head of the land') is a function of local politics and shifting allegiances that were accentuated after the introduction of cash cropping before World War II.

Vanua, then, is a segmentary concept that is context dependent for its meaning. Used rhetorically to indicate the indivisibility of the land in Ambae, in situations where alienation is likely, the 'corporateness' of the concept was, according to Allen, easily overridden up to and during the time of his fieldwork in the late 1950s (Allen 1969: 132). In a summing up of linguistic evidence, in a recent work on reconstructions of Proto-Oceanic, Green and Pawley generalise these more specific instances to PMP (Proto-Malayo-Polynesian) and Poc (Proto-Oceanic), commenting that:

although reflexes of PMP *banua carry the meaning 'village' in a number of languages belonging to different high-order subgroups (or at least are given this gloss in dictionaries) a host of other evidence, summarised in Blust (1987: 94-5, 99-100) suggests that PMP *banua and its reflexes referred primarily to an inhabited territory; not only to the land but to the human population and dwellings and all plant and animal life and other elements that contribute to the maintenance of the human community - a complex concept with no simple equivalent in European languages. ... Indeed, the single word glosses that bilingual dictionaries give for reflexes of *banua should generally be regarded not as accurate descriptions of their meaning in the source language but as shorthand translations designed to fit the categories of the target language. (Green and Pawley 1998: 63)

In the same volume from which this quote is taken, Osmond, in a chapter on horticultural practices, lists a third term, which we find distributed throughout central northern Vanuatu but which is not listed among the terms discussed in this volume. I have already quoted its Mota Lava reflex-namely ' $m o t^{\prime}$ '. Osmond 
gives the Proto-Austronesian as * $q u C a N$ and the Proto-Oceanic as *qutan, where almost all the listed reflexes have lost the initial phoneme. The translation given for the Pan is 'fallow land'; for the Poc, 'bushland, hinterland'. Two of the local reflexes listed also give 'garden' - a meaning found in North Ambrym, which one might think indicates the opposite of Vienne's quoted definition of ' mot' as wild and uncultivated land. Osmond comments that: this change of meaning is probably due to the fact that, in

Melanesia gardens are often remote from the village and surrounded by bushland, so that to go to the garden is to go into the bush. (Osmond 1998: 119)

This would appear to be a similar problem of translation rather than contradictory meaning as noted above. This overview of north central Vanuatu foregrounds vanua as a place word; in the next section, I turn more specifically to North Ambrym, where other words are prominent in the discourse of land, place and precedence.

\section{The Vocabulary of Place in North Ambrym}

Place-dwellers know where they are and tend not to identify places in the same way that their neighbours do and certainly not as Europeans often insisted they should. While domains and specific areas in them are commonly named descriptively in North Ambrym, as, for example, 'on the beach' (ranon), 'by the bulua tree' (lonlilibulua), 'over the sea' (fante, the North Ambrym designation of Malakula), Ambrymese had no name for the entire island until Cook, in what is now a contemporary legend, named it for them. The explorer, who now stands for 'the first European', did indeed name the island though he did not land there. He is said to have misheard the phrase of those who offered a welcoming gift. 'Am rem' ('your yam'), the men of Fona declared as they handed over the tuber, appropriately, though unwittingly, as the legend has it, conferring on their island the name of the cosmically iconic crop that stands for transformation, connection and life itself.

In North Ambrym, the three most important words used to refer to land and place are ' $t a n^{\prime}$ ', 'ot' and 'vere'. While there is no reflex of 'vanua', the word 'vere' has the broad connotations that we find elsewhere with vanua and its variants, for what Rodman refers to as 'lived space'. Its etymology is unclear but there are perhaps some clues in another Poc place term isolated by Green and Pawley (1998). They list Poc *pera(?), translated as 'settlement, open space associated with a house or settlement', and some of the reflexes they list approximate the North Ambrym vere. However, they note that while

[ ${ }^{*}$ pera is] well attested in both major subgroups of Southeast Solomonic [it has] only one secure external cognate, in Manam. The range of 
meanings or glosses associated with this cognate set makes it impossible to make a firm semantic reconstruction either for Poc or for Proto Southeast Solomonic. Our best guess is that *pera referred to some sort of settlement or space associated with this. (Green and Pawley 1998: 63)

Vere, like vanua, has a somewhat broader reference than the word ' $o t$ ' discussed below, as when the people of West Ambrym refer to the north as 'vereha' (which I would tentatively translate as 'the origin place', where ' $h a$ ' has the connotation of staying forever). Mweneng vere could be translated as 'my island' or 'my place' in the general sense, where mweneng means 'my'. ${ }^{2}$

' $O t^{\prime}$ in North Ambrym usually appears in a compound as an adverbial form. It seems to connote a more specific place where people have left their mark. So lonor, which translates literally as 'in the place', means 'garden' or cultivated land; when compounded with a named residential locality, it identifies the place, e.g. ot Fona- Fona village. It appears to me to be a more specific marker that we could translate as 'domain' and although it is presumably related to the Banks Island word ' $m o t$ ' that Vienne mentions, its connotations as noted above contain the sense of the wild and uncultivated and the specificity of inhabited space. It rarely, however, seems to be possessed. Specificity of place, as when one says lonotgea, 'in this place', seems to be the defining feature of this word. In its connotation of 'wild' space, we find the reference by the saltwater-dwellers to those of the hinterland as 'taot' - the bush-dwellers. Nonetheless, there is semantic overlap between ' $t$ ' and 'vere'; the period of ritual proscription during the major politico-religious rituals of the mage were referred to as 'otkonkon' and 'vere' mokon': the first refers to the place as sacralised (being kon) and thereby proscribed - 'the sacred place'; the second to the process of making the domain sacred - 'the place has been sacralised'.

Despite family resemblances in the three words for land and place, the major difference lies between ' $o t$ ' and 'vere' on the one hand and 'tan' on the other. 'Tan' which also connotes place, means more particularly and, as in the Banks and elsewhere in northern Vanuatu, 'earth', 'ground' and 'productive land'; its prime reference being to fertility, generativeness and transformative power. Moreover, this distinction is marked linguistically.

\section{The 'Grounds' for Being}

In many Austronesian languages, particularly those of Melanesia, we find interesting variations in the use of possessives. There is, for example, a major distinction between things such as body parts and kinsfolk that are inalienable and other things that are 'alienable'. In the former case, also referred to in the literature as 'direct' or 'zero possession' (Lynch 1982), the pronoun is suffixed to the noun root (or 'head nominal'). Two examples from North Ambrym to illustrate are tabling, 'my body' (where tabli is the root and $n g$ the first person 
pronominal suffix), and raheng, 'my mother' (where rahe is the root and ng the suffix 'my'). In many Western Oceanic varieties of Austronesian, however, the alienable category is further divided according to the class of nouns referred to. ${ }^{3}$

The Ambrym case appears to be interesting in that the 'alienable' category is subdivided into a more than usual number of classes for the region. In the language of North Ambrym, there are six varieties of alienable possessive. Paton, the Presbyterian missionary linguist who published a grammar of Lonwolwol, the similar language of West Ambrym, distinguishes them as a 'common' set for ordinary things, and five other sets, which apply respectively to containers, fire and torches, liquids, maritime vessels and food. This last category, however, does not apply simply to food, as Paton notes (1971). Macintyre, in a paper on pigs in Tubetube, a community of Austronesian speakers in the Massim, notes that this category is often designated as indicating edibility but just as often contains 'a puzzling array of things', including, for example, appearance, height and enemies (1984). On the basis of the way in which these possessives are used in the Massim region, Macintyre suggests calling this a class of semi-alienable things that indicates mutability and transformation. Linguists have more commonly talked about this category as the one in which the food marker is used to indicate passive possession, such as 'actions over which the possessor has no control where he is the patient, target, or involuntary experiencer' (Pawley, cited in Lynch 1996: 96). ${ }^{4}$

In the anthropological literature on the use of possessives in Vanuatu in relation to land (such as it is), some distinctions have been made that appear not to be related to the linguistic arguments about possession. Margaret Rodman notes that in the Longana district of East Ambae, Vanuatu, 'land is not like other possessions. A distinction is made between things that move or grow, such as trucks, animals, or gardens under cultivation, e.g. bulengu rivurivu and land in general or uncultivated land, nongo tano, 'my land', and my unplanted garden'(Rodman 1989: 38-9). While the latter take the 'ordinary' possessive, the former takes the one Macintyre refers to as the 'semi-alienable'. In Ambrym, however, the words for garden and place, ' $o t$ ' and 'vere', take the ordinary possessive, while 'tan' whether cultivated or not, takes the semi-alienable one. In a parallel way, individual items of food and food in general take the semi-alienable, or what we might better call the 'transformative', possessive, while vegetables, piled up in a composite heap called a helat to be displayed and then given away, take the ordinary alienable possessive.

The significance of the distinctive use of possessives lies, I would argue, in the properties of the earth, its transformative and generative potential. Classed together with those things that it transforms, such as the father whose dismembered body produced yams in all their variety that are fed to humans 
and tusked boars, the huge yams that represent men and are exchanged at all moments of life crisis, the sacramental boars that also transform into humans or indeed were human, the plants out of which autochthonous ancestors sprang, the land itself possesses and transforms the people who emerged from it and remain connected to it. There is no space here to document fully the mythopoetic nexus between people, land and its products including humans (but see Patterson 2002), a nexus that is commonly noted for Melanesia (see Weiner 1998: 139). But, as Weiner points out, invoking Heidegger, the 'ground' or 'earth' also represents the 'grounds for' or origin of being. The origin of things, in North Ambrym, barite, in Bislama, their stampa, or 'root', is frequently located in the material transformative power of the earth in particular places and indeed in 'placement' itself. ${ }^{5}$

Tan, then, in the Ambrym context, has a range of cosmological associations that are not so evident in the other place words. The French missionary Tattevin recorded a myth from South Pentecost, also known in North Ambrym, which has a cognate language, in which the first men, a group of six brothers, emerge from a coconut tree (1929-31). The eldest instructs the others to collect Tahitian chestnuts (Inocarpus edulis or namambwe in Bislama) and to roast them. Taking a roasted nut, the eldest throws it at the youngest to whose genitals it attaches. When he attempts to pull it off, his genitals come with it, transforming him into the first woman, called Sermorp, the split chestnut. ${ }^{6}$ The brothers live together in a communal house and Sermorp in a separate dwelling. Barkulkul, the eldest, sends them in turn to request various items from their metamorphosed brother ostensibly in order to see what she will call them - each is addressed by one of the five categories of unmarriageable relative, until Balkulkul himself is revealed as the one she will marry when she addresses him as 'my dear sorcerer'. Apart from the establishment of the categorical elements of the kinship system, the myth isolates several categories of things that approximate - with a little creative interpretation - most of the alienable categories that are distinguished by noun markers in the language of North Ambrym: viz. fire (given to the one she addresses as 'brother'), sea shells, which we can equate to 'maritime vessels' (given to 'father'), vegetable food (given to the one she calls 'cross-cousin'), bamboo, which we can equate with 'containers' (given to 'mother's father'), salt water (given to her 'son') and fresh water (given to her 'husband'). The last two belong to the same general category (mukuen) from a woman's point of view and both are associated in the myth with liquids. ${ }^{7}$

Another curiosity of possessive marking in Ambrym that Paton found inexplicable is that the word for 'house' takes not the general possessive marker but the marker for liquids. The word for house is ' $\mathrm{im}$ ' but it also signifies, as is common in Austronesian societies, and indeed in many other parts of the world, an important descent group. In North Ambrym, this is the cognatic stock called the buluim or bulufatao, the 'doorway', rather than the house itself. This 
ancestor-focused descent group, I have argued elsewhere, symbolises 'flow' and 'flux' - one travels through it as women are sent forth and reclaimed in the recursive marriage pattern, also common in such societies (Patterson 1976, 2001). That the fixed abode should be marked by the possessive for 'flow' or liquid seems particularly appropriate.

The link between transformative ground, and the doorway to a house built on it, is the path or road, which also symbolically represents certain kinsfolk. Paths flowing through doorways, as women and some male kin are said to do, are aspects of association with the more fixed quality that characterises the primordiality of the named domain. The origin of these landscapes replete with signification lies in a myth we find widely, but variously distributed, in the Austronesian world. In North Ambrym, the creator spirit, Batgolgol (cf. Barkulkul in the kinship naming myth quoted above), already encountered in another mythic context as the creator of women, is now identified with the Christian deity and is credited with having 'produced all things'. On his creative path around the north of the island, however, he discovered several autochthonous beings already in residence (Patterson 2002a). He is said in one origin myth to have begun on the rugged east coast but when he arrived at the place called Barereo, he found an opposite-sex sibling pair who had hatched from the eggs of a small bird called tilala. Unimpressed by him, the man said to Batgolgol, 'I'm here, this is my place; you go and do your work somewhere else.' When he finally arrived on the east coast at Fona, Batgolgol found Bungyam, whose role is much more significant than the other autochthonous beings mentioned. In a series of apparently attenuated myths collected by the Catholic missionary in the vicinity of Olal, Bungyam and Batgolgol appear in another relationship commonly found in northern Vanuatu where one culture hero is clever, the other not. The significance of the 'stupid' hero lies in his connection to the earth. However nothing is as simple here as it may appear. In other myths known in North Ambrym and South Pentecost, Batgolgol is the great chief from whose dismembered body yams grow. In the version that I collected, the creator of yams is referred to simply as a great chief (jafu - a reflex of ratu). Sacrificing himself for his children, the father is killed, cut up and 'planted' by his youngest son. From his body spring forth all the varieties of yam that sustain his sons and all Ambrymese (Patterson 2002a).

\section{Placement and Precedence}

In their localised aspect, bulufatao somewhat resemble conical clans, with agnatic segments ranked in relation to their proximity to the apical or founding ancestor, but I did not find that any but the senior segments were differentiated, and then only by placename from the rest. Members of the senior segment keep the knowledge of the links to the founder and the narratives that link female descendants to other places. Old ceremonial grounds, where powerful rituals 
were performed in the past, are referred to as ot hanglam or 'tabu' grounds and every domain has at least one such dangerous site. Five of them are known to be so powerful that simply burying or even placing something that was in close association with someone in one of these will cause the person to die. Four of these domains, namely Hawor, Halhal, Fonteng and Metamli, feature in the narrative of Batgolgol's creative journey as origin sites of autocthonous beings, while the last, called Bulum' no (meaning the 'hole of sores'), is in an area now uninhabited in the vicinity of sulphurous springs.

In the Ambrymese landscape, every element is replete with signification; flora and fauna might be either or both sacred and utilitarian. Distinguished and identified in a hierarchy of inherited intellectual property rights, they are simultaneously pharmacopeia, and the means of daily sustenance. Senior members of a domain hold the knowledge of its sacred and dangerous places, and it is they who control access to its products. Edible or not, sequestered or free, the cosmoscape is created from the bodies of humans and is the very source of their being. The ground itself, that is, the 'tan', is constitutive of the descendants of those who originated from it, absorbing the power of the ancestors who dwell in and around it, protecting its own and tormenting interlopers. In Fona, the domain of the demiurge Bungyam, where his descendants nurture the planting and harvesting of yams in an annual cycle, the spirit or tegar that inheres in this powerful place can afflict any non-descendants of the founder should they witness the planting of first yams by any of the founder's agnatic descendants, if they trip and fall into the hole of a harvested yam, or break a new yam from the Fona crop. Only recourse to exorcism performed by the yam master will prevent the interloper's death.

Another indication of the power of Bungyam's domain is the ritual divination of death performed by the yam master on the morning when the first yams are to be removed from the ground at Fona, inaugurating the northern harvest in a carefully timed sequence of domains that proceeds from west to east, in the direction opposite to that of the creator deity's journey. Taking the sacred sign of the yams (muyune rem) in his hand, the yam master sits in the mel (men's house) and sweeps it first to the right and then, changing hands, to the left. ${ }^{8}$ He continues until he feels a sensation of cold on one side or the other, indicative of the location of the domain in which there will be a death. Although not caused by the yam master's action, the death is intimately connected to the power of the Fona domain tegar at this time of the removal of the iconic crop. While northern domains have clearly risen and fallen as sites of political eminence, or more recently been obliterated by depopulation, the precedence of the yam cycle remains embedded in the mythopoesis of contemporary life transforming the planting and harvesting sequence into a series of Christian first-fruits ceremonies where the crops are blessed in the sacred spaces of the church. Nonetheless, they must begin, as always, with Fona. 


\section{'Finishing the Land'}

I want to turn now to the metaphor of my title, which is itself a title. Tan Monong means literally 'the ground is finished', but its sense is comparable with the English phrase 'known throughout the land' in the sense of 'renowned throughout the land' and can be translated as 'lord of the land'. It is a male title acquired by the performance of a rite called mage ne kuman, the significance of which is that it belongs neither to what I have referred to elsewhere as the indigenous mage of north Ambrym nor to the hierarchy of grades imported from Malakula known in the literature as the 'graded society' and also called mage (see Patterson 1981, 2002b). Although in some regions these rights are predominantly secular, in Ambrym the mage was, in its indigenous form, an instantiation of cosmology as well as the creative basis of status differentiation between individuals and groups.

Some time in the period before European contact, these rites were augmented by the apparently piecemeal acquisition of a similar but more hierarchical and elaborate complex from the neighbouring island of Malakula. The significant difference between the indigenous rites and the imported ones was that the former necessarily involved transactions between kin and those allied in marriage, whereas the imported ones were completely independent of such requirements. One could be inducted into one of the new 'grades' by anyone who had himself acquired it. The majority of the grades came into North Ambrym from the south-west bay area of Malakula via West Ambrym, but the two highest grades were imported from the small islands off the north-east coast. Somewhere in the hiatus between the acquisition of the two sets of rituals, the anomalous mage ne kuman arrived in Ambrym, according to legend, delivered by a woman from Ambae who came ashore at Ranon on the north-west coast, in a canoe made of coconut leaves. This rite, also called a mage, differs in almost all its elements from the imported kind but in the participation of female kin of both the initiate and the sponsor, it resembles the indigenous mage. And, like these latter rites, participation depended on having reached a certain level of the imported grades. The transfer of boars in the rite is unique. The sacrificial tusked boar that gives the right to the title Tan Monong must be given to the candidate by his father or a classificatory 'father' who then also acts as donor of the pigs that are exchanged with the sponsors for ritual insignia. In all of the imported mage, the candidate gives the pigs directly to the sponsors himself. In mage ne kuman, the candidates's mother or 'mothers' (the wives of his father[s]) rather than his own wife, then sacrifice[s] boars to receive the title Jamarkon. With the receipt of this title, such women must observe, like high-ranking mage men, the restrictions on commensality with those of lower grade. However, on completion of the rite, they could now share their food with boys who had made the first grade of the imported series. 
Mage ne kuman, like the indigenous rites, may be repeated but unlike them must always be acquired from specified kin. It was available, however, only to a man who had already achieved the difficult upper grade of meleun or he could attempt it if he had reached the lesser (seventh) grade of wurwur, provided that his father had reached the highest imported grade of mal. But while its elements are specifically North Ambrymese, particularly in the involvement of kin, its provenance is just as specifically foreign and not just foreign but female. The Ambae woman who brought it is said to have been mistaken for a man because she was wearing a mat skirt and had 'the firm breasts characteristic of the women of her place' (Guiart 1951: 68). When a man noticed the damp spot on a stone that she had sat on, realised she was a woman and made advances towards her, she took a canoe at night and went back to Ambae, leaving her ritual with the people of Ranon. Like the other indigenous rites, mage ne kuman had not been performed in the north since just before World War II. The French ethnographer Jean Guiart, who was in Ambrym just after the war, was given an account of the rite by his informant, John Manu, who had performed it, and I was given an account by the yam master of Fona domain whose father had performed it. ${ }^{9}$ Its memory lingers in ancestral names and in the frequently retold deeds of the hero Tan Monong Bariu -'Lord of the Land, the warrior' — whose exploits made him the archetypal jafu gatlam or great man of the past. I heard his story many times, particularly when I asked for the definition of 'a great man'. His story did not, however, concern his prowess as a fighter in battles against enemies. It concerned the murder of his father-in-law. ${ }^{10}$ Compensating his affines with tusked boars after this shocking crime, he retrieved his wife from her natal place, and exchanged her for a 'sister' also visiting her birthplace, married, perhaps significantly, to a man of Fona and pregnant with that man's child. Proceeding to successfully complete a difficult ritual of the indigenous mage that required a great many tusked boars and access to a fund of metaphysical power, he invited the husband of the woman he had appropriated and to whom he had given his own wife, to contribute to the exchanges with kin at the birth of 'their' child. By these acts he became a truly great man who had 'finished the land'.

The story achieves mythic dimensions, I would argue, precisely because it ignores the ascendancy of the later imported rites, in favour of a thoroughly indigenised version of a foreign rite by whose title the hero is known, while demonstrating that what really makes a lord of the land is the ability to transform the inalienable ties of kinship. In appropriating the child of the descendant of another origin site with whom he does not share maternal origin, he demonstrates his supreme helan or power.

A man could thus 'finish the land' by achieving great renown, renown that had local and endogenous origins. There is, however, another way in which North Ambrymese speak of the land being 'finished'. The move to cash cropping that began in a small way along the coast between the two World Wars 
accelerated after World War II, so that many coastal domains had planted much of the flatter areas with coconuts. Ambrym, with active volcanoes at its core and much of the inland in the north steep rainforest, has a dearth of arable land in some areas and, in some depopulated domains, a plentiful supply. Nonetheless, in the rhetoric of the late Sixties, the deep division between the majority of Christian converts and their neighbours and kin in 'the bush' was expressed not only in the former's fear of the latter's sorcery but in the conviction of the bush-dwellers that Christian's were 'finishing' the land by cash cropping. The importance of yam cultivation went beyond subsistence, as will be clear from the previous section. The custodians of kastom, as the bush-dwellers saw themselves, complained bitterly about the declining varieties of yams, the curtailment of adequate fallow periods and the resultant poor crop quality and the encroachment of coconuts and coffee on land they felt should be reserved for yam gardens. Even more bitter and sometimes violent were the disputes over the bush-dwellers' pigs rooting out their Christian neighbours' coconuts or spoiling their unfenced gardens. Bush-dwellers fenced their gardens, leaving all but their valuable and cosseted tuskers to free range. The copra vs. pigs war was won when the Condominium Government decreed that all pigs must be fenced or tethered; marauding pigs could be shot with impunity when discovered destroying crops. It was no longer possible to keep pigs in the numbers required for a vigorous ritual life.

This hostility was increased by the growing perception in the 1970s that West Ambrymese refugees who had settled, intermarried and become prosperous after the disastrous 1913 eruption of the volcano that decimated their homeland, were avatars of an intrusive modernity linked to the British Government's introduction of local councils and to a perceived promotion of one of their leaders over those who espoused their role as guardians of kastom from the bush. In the decade before Independence, it was made increasingly clear to the West Ambrymese that the previous delicate balance between primordial and exogenous origins, in which their presence in the north had so far been unproblematic, was fast giving way beneath a torrent of external rhetoric about the alienation of land in Vanuatu. Leadership and its grounds were severely contested in a way that drew on earlier models and refracted them through novel discourses about worth and value (Patterson 2002, 2003).

Very little land had been alienated to Europeans in North Ambrym, and the sole plantation owned by a French company (SFNH) was abandoned at independence, leaving the various claimants to sort out their rights to it. Disputes over this land continue. Although there had been numerous European traders up and down the coast in the past, most of whom had small parcels of land, with a single exception, they were long gone by the '60s. Despite this apparent lack of motive, however, land issues loomed large in the late '70s. Writing in the 1990s on post-independence politics in Ambrym, two educated Ambrymese 
commented that the Vanua'aku Pati's campaign on land issues at the national level stimulated a local concern with the rights of immigrants who had moved out of their own domains in the colonial period (Alpi and Laan 1995: 325).

But just as kastom people did not reject aspects of modernity that suited them, Christians, particularly of the older generation, shared basic ontological assumptions with their kastom kin and neighbours. The mage was almost defunct but access to its titles was another matter. Although there is not space here to elaborate, a hereditary tendency in the acquisition of mage titles had clearly been developing for some time as is evidenced by the way, noted above, in which the Tan Monong title could be obtained by the son of a great man who was only relatively junior in mage rank himself. It was said that the highest grades of the mage could be attempted only by those who hailed from a 'great kindred', meaning one in which immediate ancestors were of high rank. It was also accepted that men could skip grades on the death of their high-ranking fathers and take their titles at the performance of the mortuary ceremonies. These tendencies then supported the claims of Christians whose ancestors had achieved high rank, contesting the equally important notion that all Christians in the kastom sense were 'unworthy' or 'profane'. In the late Seventies, the eclipse of the kastom leader by his Presbyterian rival was a bitter blow, particularly when the latter was elected in 1975 by the chiefs of the administrative district CD2 to be the representative of kastom on the new Representative Assembly set up by the Colonial Government (see Patterson 2002b). When the Council of Kastom Chiefs (later the Malvatumauri) was established in 1977 and Willy Bongmatur, an Ambrym Presbyterian, was elected its president, the kastom bush-dwellers felt they had been betrayed. As head of this important new body, Bongmatur needed to establish his credibility at home and abroad. He was a third-generation Christian and also 'from' West Ambrym, so establishing kastom bona fides now became a priority for him. He constructed ceremonial grounds at the mission village of Ranmuwuhu in the north and another at Fanu in West Ambrym. He donned a penis-wrapper and bark belt for the first time in his life, killed boars and erected slit drums. Recognition did not have to be local and, in fact, it was a longstanding practice throughout Vanuatu to gain prestige from introducing exogenous ritual forms and materials. Clearly attested by the ascendance of the imported mage in the north and the role of the rite that conferred the Tan Monong title, the 'foreign' means to local ends had an ancient provenance. In 1978, at the closing of the Council of Chiefs in Malakula, Bongmatur gave a pig to Chief Enoch of Unua in return for the title Beranginvanu, which is translated in one hagiography of Bongmatur as 'a huge stone in a large area of land' (Aaron 1981:98). Berang in North Ambrym is, however, the name for the sculpted tree-fern image set up in the mage. In a later account of Bongmatur's rise to fame, this time by an Ambrymese relative of his wife, this title has become 'one of the highest titles on Ambrym, Peranginvanu (means the man who stands on a high 
hill or stone looking out over the whole land' (Alpi and Laan 1995: 325). That he came to hold this title, the author comments, 'attests to the widespread support and influence he had among the whole island population, despite his close association with a single political party'(ibid.). ${ }^{11}$

Bongmatur has more recently enlisted the aid of anthropologists in what perhaps is the contemporary way in which 'finishing the land' can best be accomplished. When I returned to Vanuatu in 1992, he asked me to write his life story, which he wanted published. I agreed, gave him a dictaphone to use and recorded a lengthy preliminary interview. Not long after, he was approached by Lissant Bolton, who wanted to interview him about his involvement in the Cultural Centre. He gave her 13 hours of interviews, mostly about his life and rise to fame. He has also been interviewed by anthropologist Lamont Lindstrom (1997). Bolton recently published an account of Bongmatur's activities in this period in the Journal of Pacific History, which perhaps was not quite what Willy had in mind (Bolton 1998). Now retired and living between North Ambrym and Port Vila, where he frequently speaks out on local and global issues, he has constructed his own monument, a concrete church in his village in North Ambrym. One of the major ways in which he attempted to establish his right to become the President of the Council of Kastom Chiefs when his rival pointed out that he had never killed a pig, was to respond that while it was true that neither he nor his father had been involved in the mage, and that his grandfather had reached only a middle grade, his great-grandfather had sponsored his kastom rival's grandfather's accession to the grade mal meurt, the zenith of imported rites. Since it is generally known that the major sequence of grades called mage came to North Ambrym via the west, this seemed like a clinching argument. In the north itself, however, there were many who did not support Bongmatur who pointed out that the indigenous powerful rites involving kin, for which the imported grades were merely a preparation, as they were for the rite of mage ne kuman, conferring the Tan Monong title, were not performed by Bongmatur's ancestors. Within living memory, however, Bongmatur's kastom rival's father and grandfather had performed them and their ancestor was none other than Tan Monong bariu.

In the past, fame and renown were acquired through being established in an ancestral place, even though many became known to their descendants precisely because they had come from somewhere else and had connections to other places. But tracing one's primordial origins was not enough, one also benefited by demonstrating powerful connections to the wider world, through trade in material and intellectual property as well as prowess in giving tusked boars, frequently brought from elsewhere, to one's kin. Manoeuvring oneself and one's direct descendants closer to an apical ancestor was also a reason for keeping the knowledge of primordial connections and making claims to privileged access. 
In the post-colonial period, these claims became more important in relation to access to land and rights of domicile.

When the yam master of Fona village was removed from his position, after Nagriamel, the land rights and secessionist movement, was defeated at independence, a member of a junior line in the village, and a Vanua'aku Pati supporter, was appointed in his stead. In the late 1980s, this man built himself a large new concrete well (actually a water tank) into the side of which he engraved the words 'Bungyam's well'. As village chief, he was now asserting a claim to precedence in the domain that was made possible by a totally novel situation: the obliteration of a person's once inalienable right to connection with their ancestors. His attempts to perform exorcism of those afflicted by Fona spirits were notably unsuccessful, according to the yam master's son. Once the Vanua'aku Pati lost power after an uninterrupted first decade, however, the Francophone Government was keen to see the rehabilitation of those who had been punished nationally and locally after the events of the Santo Rebellion. In 1998, the yam master received a distinguished service medal from the Government and the next year held an inauguration feast in which his eldest grandson was nominated as chief of Fona village, in an attempt to restore the position of his descendants to pre-eminence in the domain. In 1999, I was summoned to what I expected would be his deathbed, to find that he was hoping for the sort of anthropological donation given, he had heard, by the Norwegian researchers working in Ranon village in the early Nineties. With enough money, he could erect The Wilfred Koran Community Hall, a monument that would 'finish the land' in a thoroughly contemporary, yet perfectly precedented manner. He also wanted to revive the mage ne kuman ritual that confers the title Tan Monong before his death. But even if he does not succeed, the fame of this title has already broached the shores of Ambrym. John Manu, Guiart's informant of the 1940s, told the ethnographer that the ritual had been performed all over Ambrym and that his father had then taken it to Pentecost.

In February 2003, the Pacific Islands Report (http://pidp.eastwestcenter.org/ pireport/2003/February/02-03-07.htm) documented the visit of the then Prime Minister, Edward Natapei, to central Pentecost to perform 'a custom peace ceremony' after several custom chiefs, 'some of whom are Tanmonoks (paramount chiefs)', were ill-treated by police causing the chiefs to cease performing their duties while banning law enforcement agencies from the island. Achieving the exogenous status of 'paramountcy', Tan Monong has indeed 'finished the land'. 


\section{References}

Aaron, D.B. 1981. 'Chief Willy Bongmatur. National Council of Chiefs.' In B. Macdonald-Milne and P. Thomas (eds), Yumi Stanap. Leaders and leadership in a new nation. Suva: Institute of Pacific Studies, the University of the South Pacific and Lotu Pasifika Publications.

Allen, M.R. 1968. 'Report on Aoba.' Edited by Caroline Leaney. Incidental Papers on Nduindui District, Aoba Island, New Hebrides, written for the British Residency in the New Hebrides, Port Vila.

Alpi, B. and J. Laan. 1995. 'Ambrym.' In H. Van Trease (ed.), Melanesian Politics. Stael Blong Vanuatu, Christchurch and Suva: Macmillan Brown Centre for Pacific Studies, University of Canterbury, and Institute of Pacific Studies, University of the South Pacific.

Bellwood, P., J. Fox and D. Tryon. (eds). 1995. The Austronesians: Historical and Comparative Perspectives. Canberra: Department of Anthropology, RSPAS. The Australian National University.

Bolton, L. 1998. 'Chief Willy Bongmatur and the Role of Chiefs in Vanuatu.' The Journal of Pacific History, XXXIII. pp. 179-196.

Bonnemaison, J. 1985. 'The tree and the Canoe. Roots and Mobility in Vanuatu Society.' In M. Chapman (ed.), Mobility and Identity in the Island Pacific special issue of Pacific Viewpoints, 26 (1). pp. 30-62.

Bonnemaison, J. 1994. The tree and the canoe: History and ethnogeography of Tanna. Honolulu: University of Hawai'i Press.

Boulekone, V. 1995. 'Politics of Tan-Union.' In H. Van Trease (ed.), Melanesian Politics. Stael Blong Vanuatu, Christchurch and Suva: Macmillan Brown Centre for Pacific Studies, University of Canterbury, and Institute of Pacific Studies, University of the South Pacific.

Codrington, R.H. 1957 [1891]. The Melanesians. Studies in their Anthropology and Folklore. New Haven: HRAF Press.

Deacon, A.B. 1934. Malekula: A Vanishing People in the New Hebrides. Edited by Camilla Wedgewood. London: G. Routledge and Sons.

Fox, J.J. (ed.) 1993. Inside Austronesian Houses: Perspectives on Domestic Designs for Living. Canberra: Department of Anthropology, RSPAS, The Australian National University.

Fox, J.J. (ed.) 1997. The Poetic Power of Place: Comparative Perspectives on Austronesian Ideas of Locality. Canberra: Department of Anthropology, RSPAS, The Australian National University. 
Fox, J.J. and C. Sather. (eds). 1996. Origins, Ancestry and Alliance: Explorations in Austronesian Ethnography. Canberra: Department of Anthropology, RSPAS, The Australian National University.

Guiart, J. 1951. 'Société, rituals et mythes du Nord-Ambrym.' Journal de la Société des Océanistes, 7 (7). pp. 5-103.

Green, R.C. and A. Pawley. 1998. 'Architectural forms and settlement patterns.' In M. Ross, A. Pawley and M. Osmond (eds), The Lexicon of Proto Oceanic. The Lexicon and environment of Ancestral Oceanic Society. 1. Material Culture, Pacific Linguistics, Series C-152, Canberra: RSPAS, The Australian National University.

Jolly, M. 1994. Women of the Place. Kastom, Colonialism and Gender in Vanuatu. Chur (Switzerland): Harwood Academic Publishers.

Layard, J. 1942. Stone Men of Malekula. London: Chatto and Windus.

Lynch, J. 1982. 'Towards a theory of the origin of the Oceanic Possessive Constructions.' In A. Halim et al. (eds), Papers from the Third International Conference on Austronesian Linguistics, Vol. 1, Pacific Linguistics, Series C-74, Canberra: Department of Linguistics, RSPAS, The Australian National University. pp. 243-68.

Lynch, J. 1996. 'Proto Oceanic Possessive Marking.' In J. Lynch and Fa'afo Pat (eds), Oceanic Studies: Proceedings of the First International Conference on Oceanic Linguistics, Pacific Linguistics, Series C-133, Canberra: Department of Linguistics, RSPAS, The Australian National University. pp. 93-110.

Macdonald-Milne, B. and P. Thomas. (eds). 1981. Yumi Stanap. Leaders and leadership in a new nation. Suva: Institute of Pacific Studies, the University of the South Pacific and Lotu Pasifika Publications.

Macintyre, M. 1984. 'The Problem of the Semi-alienable Pig.' Canberra Anthropology, 7 (1-2). pp. 109-121.

Paton, W.F. 1971a. 'Tales of Ambrym.' Pacific Linguistics, Series D-10. Canberra: Department of Linguistics, RSPAS, The Australian National University.

Paton, W.F. 1971b. 'Ambrym (Lonwolwol) Grammar.' Pacific Linguistics, Series B-19. Canberra: Department of Linguistics, RSPAS, The Australian National University.

Paton, W.F. 1979. 'Customs of Ambrym.' Pacific Linguistics, Series D-22. Canberra: Department of Linguistics, RSPAS, The Australian National University. 
Patterson, M. 1976. 'Kinship, Marriage and Ritual in North Ambrym.' Unpublished PhD thesis. Anthropology Department, University of Sydney. Sydney.

Patterson, M. 1981. 'Slings and Arrows: Rituals of Status Acquisition in North Ambrym.' In M.R. Allen (ed.), Vanuatu. Politics, Economics and Ritual in Island Melanesia. pp. 189-236.

Patterson, M. 2001. 'Breaking the Stones: Ritual, gender and modernity in North Ambrym, Vanuatu.' In M. Patterson and R. Tonkinson (eds). Special Issue: Gender, Power and Ritual in Cross-Cultural Perspective-essays in honour of Michael Allen, Anthropological Forum 11 (1). pp. 39-54.

Patterson, M. 2002a. 'Moving Histories: An analysis of the dynamics of place and mobility in North Ambrym, Vanuatu.' The Australian Journal of Anthropology, 13 (2) pp. 200-18.

Patterson, M. 2002b. 'Leading Lights in the 'Mother of Darkness': Perspectives on Leadership and Value in North Ambrym, Vanuatu.' Oceania, 73 (2). p. 126-42.

Philibert, J.-M. 1992. 'Social Change in Vanuatu.' In A.B. Robillard (ed.), Social Change in the Pacific Islands, London and New York: Kegan Paul International.

Regenvanu, S. 1980. 'The Land.' Vanuatu: twenty wan tintging long taem blong Independens. Suva: Institute of Pacific Studies, University of the South Pacific, and the South Pacific Social Sciences Association.

Rodman, M. 1987. Masters of Tradition. Consequences of customary land tenure in Longana, Vanuatu. Vancouver: University of British Columbia Press.

Rodman, M. 1992. 'Empowering Place: Multilocality and Multivocality.' American Anthropologist, 94. pp. 640-56.

Rodman, M. 1994. 'Breathing Spaces: Customary Land Tenure in Vanuatu.' In R.G. Ward and E. Kingdon (eds), Land, Custom and Practice in the South Pacific, Cambridge: Cambridge University Press.

Ross, M., A. Pawley and M. Osmond. 1998. 'The Lexicon of Proto Oceanic. The Lexicon and environment of Ancestral Oceanic Society. 1. Material Culture.' Pacific Linguistics, Series C-152. Canberra: RSPAS, The Australian National University.

Sope, B. (ed.) 1974. Land and Politics in the New Hebrides. Suva: South Pacific Social Sciences Association.

Tattevin, E. 1929-31. 'Mythes et legends du sud de l'île Pentecôte.' Anthropos, 24: pp. 983-1004; 26: pp. 489-512, 863-6. 
Tonkinson, R. 1968. Maat Village, Efate: A Relocated Community in the New Hebrides. Eugene (Oregon): Department of Anthropology, University of Oregon.

Tonkinson, R. 1982a. 'National Identity and the Problem of kastom in Vanuatu.' Mankind, 13 (4). pp. 306-15.

Tonkinson, R. 1985. 'Forever Ambrymese. Identity in a Relocated Community, Pacific Vanuatu.' In M. Chapman (ed.), Mobility and Identity in the Island Pacific, special issue, Pacific Viewpoints, 26 (1). pp. 30-62.

Van Trease, H. 1987. The politics of land in Vanuatu. From colony to independence. Suva: Institute of Pacific Studies, the University of the South Pacific.

Van Trease, H. (ed.) 1995. Melanesian Politics. Stael Blong Vanuatu. Christchurch and Suva: Macmillan Brown Centre for Pacific Studies, University of Canterbury, and Institute of Pacific Studies, University of the South Pacific.

Vienne, B. 1984. Gens de Motlav. Idéologie et pratique sociale en Mélanésie. Paris: Publication de la Société des Océanistes, No 42. Musée de l'Homme.

Weiner, J. 1998. 'Revealing the Grounds of life in PNG.' In S. Bamford (ed.), Identity, Nature and Culture: Sociality and Environment in Melanesia, special issue, Social Analysis, 42 (3). pp. 135-42.

\section{ENDNOTES}

1 This was merely, according to Van Trease, 'an extension of the New Hebrides National Party' shortly to be renamed as mentioned above and it was relatively short lived, fielding candidates at only one election (Van Trease 1987: 216).

${ }^{2}$ When I left North Ambrym after my first period of fieldwork in 1969, the kind of song competition that accompanied boys' initiation was performed at my farewell feast. In one of the new songs, the composer described me as someone who 'has come to learn the language of my place', 'mame rongtane ral ne mweneng vere'.

3 There is some controversy among linguists here. Whereas earlier writers had seen the 'alienable' varieties of noun possession as a kind of gender system, by the 1970s, Pawley and Lynch in particular argued that they expressed the relationships of possession and were more comparable to verb-object relationships. It was recognised that "possession with some nouns could be expressed by means of more than one construction, and that these nouns thus "belonged" to more than one class"'(Lynch 1996: 94).

4 In a recent view, Lynch suggests that in Proto-Oceanic, passive possession might have been marked quite differently from food possession, by a now disappeared article (as found in some Polynesian languages $-\mathrm{a} / \mathrm{o}$ ) and that there were previously a greater number of possessive markers (Lynch 1996: 97).

5 See Rodman (1995: 71-3) for an excellent overview of the ways in which connection to land has been documented in Vanuatu.

6 In North Ambrym, the husks of Tahitian chestnuts symbolise female genitalia and feature in ribald joking between women.

7 Salt water (wekon), which is referred to as 'kon' or bitter/salt/sacred/tabu, is associated appropriately with a woman's son, who she calls by the same term that she uses for her father-in-law, i.e. the boy's father's father; these kin are for her members of an avoided ('mokon') category. Fresh water (we) is 'clear' and unrestricted as husbands must be after marriage and as mothers-in-law are made to be by the sacrifice of pigs. 
8 The muyune rem (literally, sign of the yam) was sold to a tourist by the yam master's son-in-law in the early 1970s. It was described as a small bundle of sticks bound together.

9 The Presbyterian missionary Paton also records a description of the rite that appears to be somewhat muddled in relation to the identity of the protagonists (1979: 26-8). Paton does not mention the kinship relations between donor and sponsor and erroneously comments that women could take the title. While it is true that women participate in the rite, they could not initiate their participation nor participate on their own but only as mother of the candidate. Paton's description of the central act of the rite, where the husband and wife kneel covered with a red mat and are given water to drink from a vessel proffered by the sponsor who drinks first, then after they have drunk, pours water over their hands to 'wash' them, has a decidedly Christian resonance. It was not reported to me nor does it appear in Guiart's account. Paton, however, worked and lived among West Ambrymese refugees whose version of the rite might have contained these elements or they might have been added for Paton's benefit. In Paton's account the candidate takes a small pig and tosses it over the low fence that has been constructed around a section of the ceremonial ground, outside of which guests stand to observe the proceedings, rather like a bride tossing a bouquet. In fact, his account has a distinct 'wedding' quality to it. Whoever catches the pig may take it to eat with his grade mates. In Guiart's account, the water comes from a basin that is made of a leaf-lined depression in a canoe-shaped mound of earth constructed inside the coconut-leaf enclosure. At one end of the mound is a representation of a frigate bird or snake such as adorned seagoing canoes and which are also placed over the little shrines that cover the stone altars in the upper mage ranks. The candidate, who is surrounded by his classificatory fathers, must drink from the basin before sacrificing a boar and calling out his new title. His mother or 'mothers' (i.e. the wives of his fathers) then also kill pigs to take their titles, giving smaller pigs for pearl-shell armbands provided by the wife of the sponsor. This is one of the few occasions when some women were permitted into the ceremonial ground. All women other than the candidates had to participate in the accompanying dancing in the bush on the outskirts of the sacred space.

10 In need of her labour because he was planning one of the important rituals involving his mother's origin place, he wanted her back. After arguing with his wife's father and shooting him, he proceeded to his mother's place, where he could expect sanctuary. He arranged with them to pay compensation of tusked boars to the murdered man's kin, retrieved his wife and took as well another woman, also visiting her birthplace, who happened to be married and pregnant to a man of Fona village. Sending word to the Fona husband that when his child was born he should come and contribute to the birth ritual exchanges for 'their' child, he went on with his preparation for the ritual, which he completed successfully. Descendants of the 'stolen child', who was brought up by Tan Monong Bariu, still claim descent from the Fona founder though their rights to land are unchallenged in Tan Monong Bariu's domain.

11 This account also claims that he joined with Koran, the yam master of Fona, to kill a large number of pigs and take the title Molbaro, but according to Koran this was his initiative and did not involve Chief Willy. 